\title{
Co-Leader in Group Counseling: Roles, Process, and Relationships
}

\author{
Ragıp Ümit YALÇIN ${ }^{1}$
}

\begin{abstract}
It is known that the group leader has an important role and power in the therapeutically effective execution of the process in group counseling. The common sharing of this power with another leader is explained in the literature by the concept of co-leadership. Considering the nature of the counseling process, it is seen that working with the co-leader in the group brings various advantages and risks. That is why it is important for professionals who want to be involved in a similar process to describe the co-leaders' place in the consultation process, role sharing with the group leader, and the relationship of leaders with each other. In this direction, the aim of the article is to examine the place of the coleadership in group counseling process in the literature and conceptualize it for practitioners.
\end{abstract}

Keywords: Group counseling, group leader, co-leadership in the group

\section{Introduction}

In the group counseling process, it is stated that the group leader is an effective therapeutic power due to important roles and duties such as providing the therapeutic environment, supporting the development of the members in line with their behavioral goals, and contributing to the formation of other therapeutic powers. (Türküm \& Akdoğan, 2007; Voltan Acar, 2017). If this power is shared with another leader in the process, the concept of co-leadership emerges (Demir \& Koydemir, 2013). Coleadership is defined as the collaboration of two practitioners simultaneously to facilitate therapeutic action between group members and sessions (Fall \& Wejnert, 2005; Okech \& Kline, 2006).

When the literature is examined, it is seen that the co-leadership model has been used for a long time in individual therapies, group therapies, marriage, and family counseling. An example of this is Adler's use of co-leaders in individual counseling to train therapists. In addition, Moreno's use of a second leader who plays the role of a helping ego to define transference and countertransference in psychodrama can be given as another example (Luke \& Hackney, 2007; Voltan Acar, 2017). The most important element discussed in the co-leadership model was the advantages and disadvantages of this model. Apart from all these advantages and disadvantages, the effectiveness of this model depends on many factors such as the theoretical basis adopted by both leaders, their knowledge and skill levels on joint work, and the compatibility of leaders with each other (Carroll \& Wiggins, 2014; Gladding, 2008).

Leaders who aim to use co-leaders in the group management phase, in addition to their leadership skills, need to have extra knowledge and skills in order to be able to resolve possible conflicts in the group process and to control the process effectively (Posthuma, 2002). This knowledge and skills prevent the incompatibility of the leaders from harming the process and the group. From this point of

\footnotetext{
1 PhD., Atatürk University, Turkey, Faculty of Education, rgpumtylcn@gmail.com, ORCID: 0000-0003-1634-1734
} 
view, the aim of the article is to examine the place of co-leadership in group counseling practices in the literature and to conceptualize it for practitioners.

\section{Method}

This is a descriptive document review study. In this study, books, articles, and presentations referring to the concept of co-leadership in psychological counseling with a group in the Psychology literature were examined and synthesized.

\section{Co-Leadership Combinations}

The co-leadership model, which is defined as the joint execution of group consultations by two people, one leader, and one co-leader, has an important feature in that the two leaders can learn from each other by negotiating before and after the group session (Corey, et al., 2016). Within the consultation process, there are combinations that regulate the relations between the leaders and define the positions of the collaborating leaders in the consultation. Gallogly and Levine (1979) defined these combinations in three different ways. These were formed by the collaboration of two intern leaders, an intern, and an expert leader, and finally, the collaboration of two expert leaders.

Group leader candidates who are preparing to meet their first group or who receive group counseling training may feel inadequate at the beginning of the process and may exhibit symptoms based on excitement (Corey, et al., 2016). In such a case, it can be seen as an important advantage for the group leader candidate to manage the group with a co-leader who is trusted, respected, and more experienced than himself, by making use of the expert-trainee cooperation, in terms of keeping his excitement under control and making his training more effective. By making use of another combination, expert-expert collaboration, two expert group leaders from similar or different schools can observe the intervention processes they use in their consultations and give consultations to each other. This situation can be considered as an opportunity for both consultants to consolidate their expertise (Luke \& Hacney, 2007). Considering the risks such as competition and personal ambitions that can lead to power and control wars within the group, the intern-intern collaboration combination may be less preferable than the other two combinations. However, while managing difficult groups, the advantages of helping each other in many ways, even if they are trainees, should not be overlooked.

In addition to these three combinations created based on experience, another combination that should be emphasized is the cooperation consisting of one female and one male leader. Such cooperation allows the members to interact with both the same gender and a leader of the opposite gender at the same time (Demir \& Koydemir, 2013; Nosko \& Wallece, 1997). Depending on the advantages of this situation, members can have the opportunity to open up more easily and receive comprehensive feedback from advisors of different genders at the same time.

\section{The Process of Co-Leadership Models}

It is important that both counselors know their roles and responsibilities in the process of group counseling carried out with the co-leader, in order to prevent the unproductive relations that the leaders establish with each other. Both leaders can maximize the efficiency of their cooperation by acting in a complementary and harmonious manner in the process (Yalom \& Leszcz, 2008). 
Fall and Wejnert (2005) presented a model that deals with the relationship between leaders who work collaboratively in the group counseling process and explains this process. According to this model, the successive stages are defined as follows.

Forming: At this stage, both leaders make an effort to find their place in the group counseling process. The most important factor that complicates this process is that the leaders do not know their expectations for each other. In addition, leaders may not completely know what group members can expect without consultation. Although leaders have worked together before, they may experience this difficulty again in each new group process (Fall \& Wejnert, 2005).

Conflict of leaders: At this stage, a situation of conflict may arise as a result of differences in leaders. Co-leaders should see this conflict as part of the process and be prepared for it. If these conflicts are resolved in a healthy way, the sincere feelings and sense of commitment among the leaders will increase (Fall \& Hartwing, 2016).

Formation of norms: After the conflict managed in a healthy way at this stage, co-leaders have become more sensitive to each other's concerns, ideas, and personality traits (Arıcı \& Voltan Acar, 2011; Türküm \& Akdoğan, 2007). They now tend to discuss and share their roles in the process.

Implementation phase: Since the leaders are in the working phase of the group at this stage, the level of interaction of the group members will increase significantly compared to the previous phases (Naar, 2007). Morever, both leaders will try to act in coordination to preserve the interaction structure and momentum of the group. At this stage, leaders are expected to communicate their adaptation problems to each other honestly. Depending on these expectations, they do not need any external audit until the conclusion stage (Fall \& Wejnert, 2005).

Conclusion phase: The group now enters the conclusion phase at this phase. Especially at this stage, the most important therapeutic factor that leaders should focus on is the element of commitment between group members and with the leaders (Kızll \& Yalçın, 2015). Depending on this element, there is a possibility that an intense emotional state may arise among the members, which may include leaders. Both leaders may not act professionally if they are affected by this intense emotional state brought about by the closing stages. For example, old power struggles and inadequacy concerns between leaders that were previously resolved may resurface. In order to avoid such negativities and to end the group process successfully, it would be beneficial for both group leaders to come together before the last session and determine a common roadmap for the conclusion (Fall \& Wejnert, 2005).

\section{Factors that facilitate the relationship of leaders with each other}

Creating a positive group culture so that members learn how to support each other constitutes the therapeutic goal of group counseling (Sharry, 2016). This purpose is also valid in the group work carried out with the co-leader and in the relationship process between both leaders. Considering a group process that requires the joint work of two leaders for this purpose; both of the leaders who manage the group without noticing bring their personal qualities, values, and life experiences to the group process (Corey, et al., 2016). In this case, as a result of personal differences, it is inevitable that there will be a conflict between the leaders in the management of the group (Voltan-Acar, 2017). In order to overcome these conflicts in a healthy way, both leaders need to work in coordination (Atieno Okech \& Kline, 2005). 
In the group process, a certain strategy is needed in order for the relations between the leaders to work in a coordinated way and for the possible conflicts to be resolved in a healthy way. For these strategies, Fall and Hartwing (2016) adapted the seven-stage positive habit model, which is the basis of Glasser's choice theory, for the relations between the leader and the co-leader. The strategies obtained as a result of this adaptation are defined as follows.

Listening: Group leaders should not only be limited to the group process, but should also effectively listen to each other outside of the sessions and constantly exchange information about the structure of the group. This habit facilitates the establishment of a healthy and professional relationship between the two leaders (Fall \& Hartwing, 2016).

Supporting: Unhealthy initiatives such as group leaders trying to shadow each other, trying to control each other's behavior, and wanting to struggle for power are harmful to both the cohesion of the leaders and the development of the group (Atieno Okech, 2008). Instead, leaders should focus on the habit of supporting each other.

Encouragement: In group sessions and in supervision sessions, leaders can record positive impressions of one another and share them later. Such attitudes and habits help to form a common leadership identity among leaders and increase cohesion (Atieno Okech \& Kline, 2006).

Respect: Group leaders develop their own style over time, based on their own experience, skills, and principles. Both leaders should try to find common ground and respect each other's style. (Bridbord \& Delucia Waack, 2011).

Confidence: Group leaders must be confident and trust each other for the techniques and interventions they use. If a leader constantly tries to test whether another leader is doing something right, as result, he will have difficulty focusing on the development of the group and may drag the process into onflict (Fall \& Hartwing, 2016).

Acceptance: Regardless of their group life, each leader should accept that the other leader exhibits his/her potential in the best way, and should avoid judging and blaming each other depending on the negative situations experienced (Fall \& Hartwing, 2016).

Negotiating on conflict: Each leader should focus on how to change their own behavior in order to eliminate conflicts and conflict situations and should be ready to negotiate the conflict mutually (A1c1, 2003).

\section{Discussion}

The co-leadership model, which can be preferred in group counseling for various reasons, offers both partners a unique opportunity to observe and learn from one another, regardless of gender, expertise and level of education. In order to get the maximum benefit from this chance, the quality of the relationship between the leaders gains importance in the consultation process. When the literature on the co-leadership model is examined, it is seen that most of the problems experienced by the co-leaders in their relationships are quite similar to the behavioral problems of the group members in the process (Fall \& Wejnert, 2005). Researchers focusing on the disadvantage of co-leadership cite the problems that can be experienced in this relationship (Berger, 2002; Cohen \& DeLois, 2001). Raising awareness to 
practitioners about these problems can help spread co-leadership in group consultations. For this, it is important for professionals who receive group leadership training, regardless of the theory, to be aware of the factors that facilitate the relations between leaders and to know the situations that they may encounter in the joint leadership process. As a result, it will increase the success and efficiency of professionals working in the field of group counseling when they conduct together with a co-leader in their groups. On the other hand, the use of the co-leadership model of training professionals to increase the experience of students in group-related practice courses will improve the quality of education. There is no clear unity of practice in the training program on group counseling in Turkey. Therefore, expertintern or intern-intern co-leadership combinations can be used in group counseling training in Turkey.

\section{References}

Arıc1, F., \& Voltan-Acar, N. (2011). Grupla psikolojik danışmada terapotik bir güc, olarak psikolojik danışman. Türk Psikolojik Danıșma ve Rehberlik Dergisi, 4(36), 173-179. Retrived from https://eds.p.ebscohost.com/eds/pdfviewer/pdfviewer?vid=0\&sid=470ed4d9-b4d3-407d-8bcb3135 cc3126e $4 \% 40$ redis

Atıcı, M. (2003). İstenmeyen davranışlarla başa çıkmada Glasser'in problem çözme yaklaşımının uygulanması. Eğitim ve Bilim, 28(27-34). Retrieved from http://egitimvebilim.ted.org.tr/index.php/EB/article/view/5131/1213

Atieno Okech, J. E. (2008). Reflective practice in group co-leadership. The Journal for Specialists in Group Work, 33(3), 236-252. DOI: 10.1080/01933920802196138

Atieno Okech, J. E., \& Kline, W. B. (2005). A qualitative exploration of group co-leader relationships. The Journal for Specialists in Group Work, 30(2), 173-190. DOI:10.1080/01933920590926048

Atieno Okech, J. E., \& Kline, W. B. (2006). Competency concerns in group co-leader relationships. The Journal for Specialists in Group Work, 31(2), 165-180. DOI:10.1080/01933920500493829

Berger, M. (2002). Envy and generosity between co-therapists. Group, 26, 107-121. DOI: 10.1023/A:1015430913790

Bridbord, K., \& DeLucia-Waack, J. (2011). Personality, leadership style, and theoretical orientation as predictors of group co-leadership satisfaction. The Journal for Specialists in Group Work, 36(3), 202-221. DOI: 10.1080/01933922.2011.578117

Carroll, R., M., \& Wiggins, J., D. (2014). Elements of group counseling concepts, principles and practices (Traslaters: S. Doğan, I. Başaran, M. Aladağ, B., \& Yaka, T.). Ankara: Pegem Academic

Cohen, M. B., \& DeLois, K. (2001). Training in Tandem: Co-facilitation and role modeling in a group work course. Social Work with Groups, 24, 21-36. DOI: 0.1300/J009v24n01_03

Corey, M., S., Corey, G., \& Corey, C. (2016). Psychological counseling groups process and practice (Translaters: F. Aysan, S. Balcı-Çelik, \& A. Uz-Baş). Ankara: Nobel Publishing

Demir, A., \& Koydemir, S. (2013). In group counseling. In Y. Kağnıc1 (Ed.), Leadership in psychological counseling groups (pp. 201-222). (3 th Edition). Ankara: Pegem Academic 
Fall, K. A., \& Hartwig, E. K. (2016). Using choice theory to conceptualize co-leader relationships in group work. International Journal of Choice Theory and Reality Therapy, 36(1), 81. Retrieved from https://www.wglasserinternational.org/wpcontent/uploads/bskpdfmanaer/IJCTRT_Fall2016_20 0.pdf\#page $=81$

Fall, K. A., \& Wejnert, T. J. (2005). Co-leader stages of development: An application of Tuckman and Jensen (1977). The Journal for Specialists in Group Work, 30(4), 309-327. DOI: $10.1080 / 01933920500186530$

Gallogly, V., \& Levine, B. (1979). Co-therapy. In B. Levine (Ed.), Group psychotherapy: Practice and development (pp. 296-305). Waveland: Prospect Heights, IL

Gladding, G. M. (2008). Groups: in A counseling specialty (5 th Edition). New Jersey: Pearson Prentice Hall.

Kızıl, Z., \& Yalçı, İ. (2015). A therapeutic factor in counseling with the group: Commitment. Journal of the Faculty of Education of Mersin University, 11(3). DOI: 10.17860/efd.26138

Luke, M., \& Hackney, H, (2007). Group coleadership: A critical review. Counselor Education \& Supervision, 46, 280-293. Retrieved from https://onlinelibrary.wiley.com/doi/epdf/10.1002/j.15566978.2007.tb00032.x

Naar, R. (2007). First step to group psychotherapy (Translater: N. H. Şahin) Ankara: İmge Publishing

Nosko, A., \& Wallace, R. (1997). Female / Male co-leadership in groups. Social Work with Groups, 20(2), 316. DOI: 10.1300/J009v20n02_02

Posthuma, B. W. (2002). Small groups in counseling and therapy process and leadership (4 th Edition). Boston: Allyn \& Bacon.

Sharry, J. (2016). Psychological counseling with a solution focused group (Translaters: D. M. Siyez, Y. Soylu, Ü. Arslan, E. Esen, \& T. Bağatarhan). Ankara: Nobel Publishing.

Türküm, S., \& Akdoğan, R. (2007). Leader as a professional and as an individual in group counseling. Turkish Journal of Psychological Counseling and Guidance, 3(27), 123-137. DOI: 10.17860/efd.26138

Voltan-Acar, N. (2017). Group counseling principles and techniques (12 th Edition) Ankara: Nobel Publishing

Yalom, I. D., \& Leszcz, M, (2008). The Theory and practice of group psychotherapy (5 th Edition). New York: Basic Books. 